\title{
Dynamic Process of Prostate Cancer Metastasis to Bone
}

\author{
Kwanchanit Tantivejkul, Linda M. Kalikin, and Kenneth J. Pienta* \\ Departments of Urology and Internal Medicine, Division of Hematology and Oncology, The Michigan \\ Urology Center at The University of Michigan Comprehensive Cancer Center, Ann Arbor, Michigan 48109
}

\begin{abstract}
Prostate cancer metastasis to the bone occurs at high frequency in patients with advanced disease, causing significant morbidity and mortality. Over a century ago, the "seed and soil" theory was proposed to explain organ-specific patterns of metastases. Today, this theory continues to be relevant as we continue to discover factors involved in the attraction and subsequent growth of prostate cancer cells to the bone. These include the accumulation of genetic changes within cancer cells, the preferential binding of cancer cells to bone marrow endothelial cells, and the release of cancer cell chemoattractants from bone elements. A key mediator throughout this metastatic process is the integrin family of proteins. Alterations in integrin expression and function promote dissociation of cancer cells from the primary tumor mass and migration into the blood stream. Once in circulation, integrins facilitate cancer cell survival through interactions between other cancer cells, platelets, and endothelial cells of the target bone. Furthermore, dynamic changes in integrins and in integrin-associated signal transduction aid in the extravasation of cancer cells into the bone and in expansion to a clinically relevant metastasis. Thus, we will review the critical roles of integrins in the process of prostate cancer bone metastasis, from the escape of cancer cells from the primary tumor, to their survival in the harsh "third microenvironment" of the circulation, and ultimately to their attachment and growth at distant bone sites. J. Cell. Biochem. 91: 706-717, 2004. (C) 2003 Wiley-Liss, Inc.
\end{abstract}

Key words: prostate cancer; integrins; metastasis; cell adhesion; bone; signal transduction; RhoGTPases

Prostate cancer is the second most common cause of cancer-related deaths among men in the United States [Jemal et al., 2003]. It is estimated that 220,900 new cases will be diagnosed and 28,900 deaths will occur in 2003. Approximately $90 \%$ of advanced stage prostate cancer patients develop bone lesions causing morbidity that includes bone pain, immobility, hematopoietic compromises, and spinal cord compression [Bubendorf et al., 2000; Rubin et al., 2000]. Current treatments are not curative, and patients have a median survival time of $9-$ 12 months after becoming hormone refractory [Cheville et al., 2002].

Ellis et al. [2003] reported that prostatespecific antigen- (PSA-) expressing epithelial cells were detected in bone marrow samples

*Correspondence to: Kenneth J. Pienta, MD, Department of Internal Medicine, Division of Hematology and Oncology, The University of Michigan Comprehensive Cancer Center, 7303 CCGC, 1500 East Medical Center Dr., Ann Arbor, MI 48109-0946. E-mail: kpienta@umich.edu

Received 29 July 2003; Accepted 1 August 2003

DOI 10.1002/jcb.10664

(c) 2003 Wiley-Liss, Inc. from 60 of 126 (54\%) patients with localized prostate cancer before radical prostatectomy, while only 33 of 138 (24\%) patients had detectable PSA-expressing epithelial cells in peripheral blood. This finding supports the preferential enrichment of cancer cells in the bone marrow as an early metastatic event and leads to many interesting questions pertinent to prostate cancer metastasis. How do the cancer cells outgrow and escape from the primary site? How do they survive shear forces present in the circulation and evade immunosurveillance? How do these cells interact with the target bone endothelium? What factors in the bone microenvironment attract prostate cancer cells and prompt them to initiate growth? Understanding the biological processes leading to the establishment of clinically relevant bone metastases is not just an intellectual exercise as the answers to these questions may lead to invaluable therapeutic strategies to treat the currently incurable disease of advanced prostate cancer.

\section{HISTORICAL PERSPECTIVE OF CANCER METASTASIS}

Metastasis is a multi-step process that includes growth in a primary organ, neoangio- 


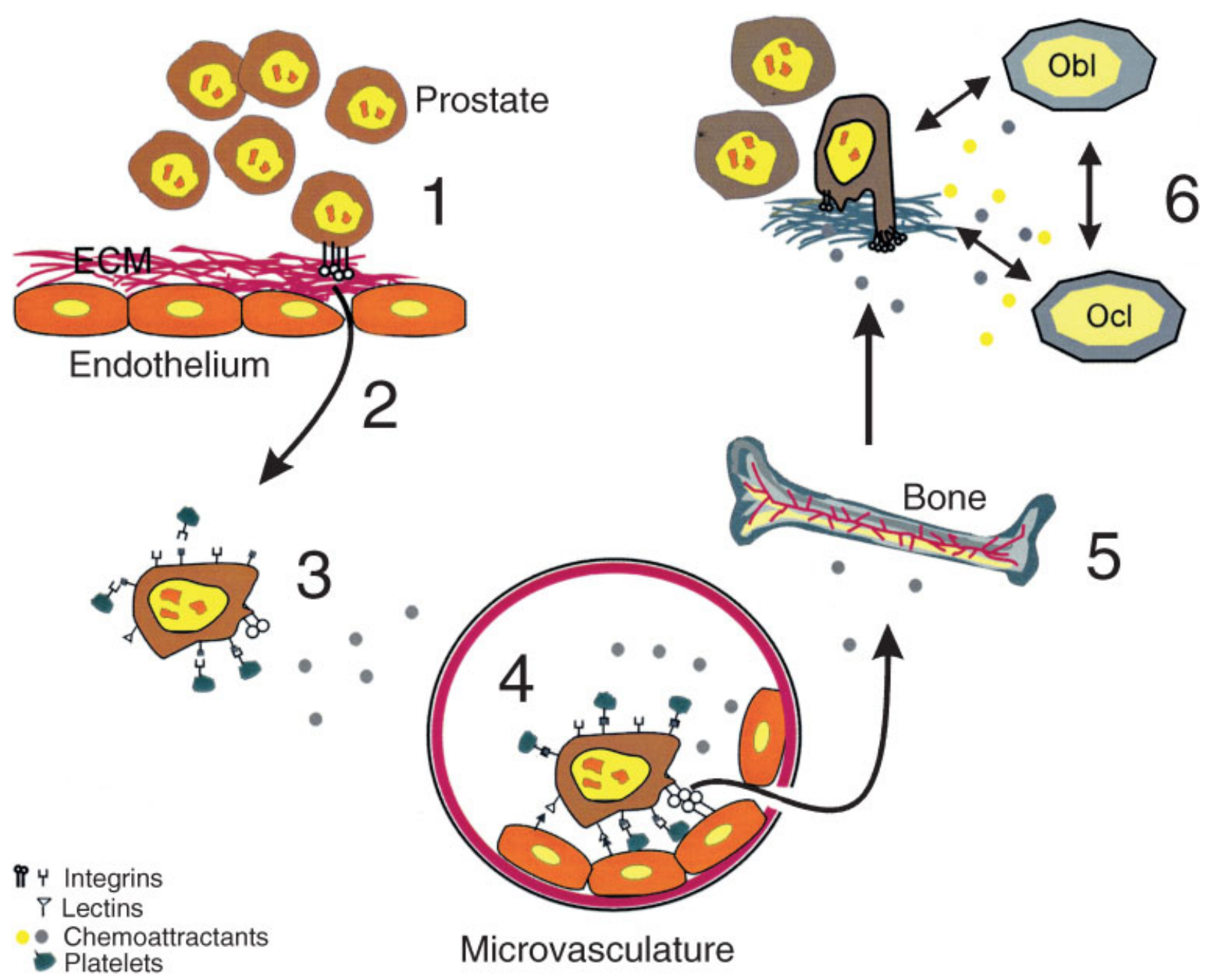

Fig. 1. Steps in prostate cancer metastasis to bone. Successful metastasis is a multi-step process that includes (1) growth and escape from a primary organ, (2) intravasation, (3) survival in circulation, (4) chemoattraction and extravasation, (5) and growth in bone through (6) cross-talks with osteoblasts and osteoclasts. These steps require the ability of cancer cells to adhere to and migrate across the surrounding extracellular matrix (ECM), actions mediated by the integrins.

genesis, intravasation into and survival in circulation, attachment to a distant target organ, extravasation at that site, and growth of a secondary neoplasm and, as such, appears to be an inefficient process (Fig. 1). While organspecific localization of luciferase-labeled PC3 human prostate cancer cell line cells was visualized by non-invasive imaging $15 \mathrm{~min}$ postintracardiac injection in immunocompromised mice, no viable cells were detected $24 \mathrm{~h}$ later. Despite this indication that most of the injected cells were either dead or metabolically inactive, skeletal and soft tissue micrometastases were apparent on imaging several days later and were confirmed histologically and radiographically weeks later [Rosol et al., 2003]. Similarly, intravital videomicroscopy of various types of cancer showed that only $2 \%$ of cancer cells formed micrometastases [Luzzi et al., 1998; Varghese et al., 2002]. Furthermore, 99\% of these micrometastases failed to form larger tumors, although numerous solitary cells remained detectable in the tissue months after injection [Naumov et al., 2001, 2002; MacDonald et al., 2002].

Stephen Paget [1889] was the first to present an explanation for the non-random patterns of cancer metastases. His "seed and soil" theory proposed that there was something about metastatic sites that promoted cancer cell growth similar to the tendency of seeds to grow in fertile soil, i.e., that factors in the environment at a metastatic site contributed to the proliferation of cancer cells there. Forty years later, James Ewing [1928] presented a different view 
proposing that cancer cells grew at a particular site because they were directed to that site by the direction of blood flow and lymphatics. It is likely that both of these theories are correct, at least in part. Ewing's theory accounts for cancer growth in the draining lymph nodes and the liver, but Paget's theory describes distal metastases that are organ-specific, such as metastases to the bone.

Isaiah Fidler [2002] redefined the modern "seed and soil" hypothesis as three principles. First, cancerous tissues contained heterogeneous subpopulations of cells with different angiogenic, invasive, and metastatic properties. Second, the metastatic process was selective for cells that survived the long journey to a distal organ. Finally, the success of the metastatic cells depended on the ability of those cells to interact and to utilize the "soil" provided in their new microenvironment. These properties are demonstrated by co-culture of an isolated mouse femur with PC-3 human prostate cancer cells (Fig. 2). As shown by scanning electron micrograph, after 3 days cells exhibiting diverse phenotypes are attached to the bone. We hypothesize that these variable morphologies may represent the heterogeneous population of prostate cancer cells that differentially responds to growth on bone. Alternatively, these pleomorphic cells may be in different stages of metastasis, as some appear anchored to the bone at the extended edges, perhaps "feeling" out the environment for chemotactic factors, while others seem to have formed firm adhesions with the bone, suggesting that they may have begun an invasive process.

\section{METASTATIC PROCESS AND INTEGRINS}

In normal prostate development, the interaction of prostate epithelial cells with surrounding stroma influences their growth, survival, and differentiation potential. Components of

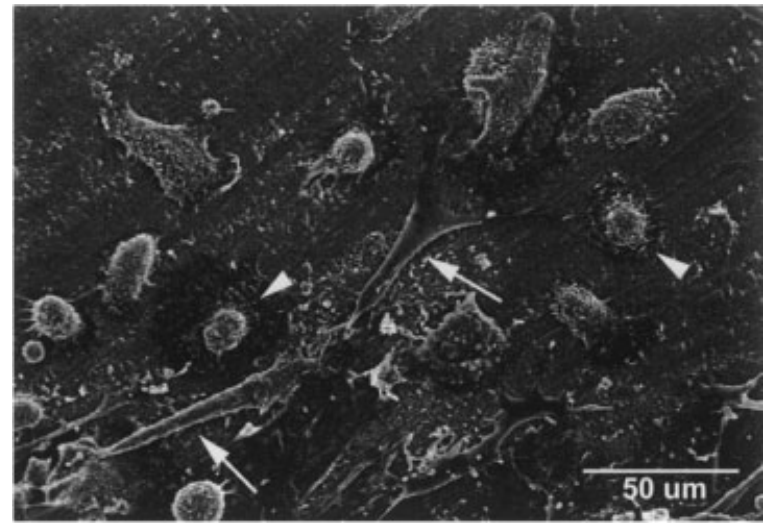

Fig. 2. Adhesion and invasion of PC-3 cells into mouse bone in an explant model. Several different cell morphologies are evident when PC-3 cells were co-cultured on mouse bone explant for 3 days, fixed with $2.5 \%$ glutaraldehyde in Sorenson's buffer and prepared for scanning electron microscopy. These cells possibly represent either a heterogeneous population of prostate cancer cells or cells in different stages of bone metastasis. Some cells are elongated on the bone, perhaps in search of chemotactic factors (arrows). Other cells exhibit halo-like area around themselves, suggesting that they have initiated the invasion process (arrowheads).

the surrounding stroma include numerous cell types, such as fibroblast, endothelial, neuroendocrine, and inflammatory cells; soluble growth factors; and insoluble laminin-rich extracellular matrix (ECM). Many of the steps in cancer metastasis involve changes in cell adhesion to adjacent cells and to the ECM. The cell surface receptor integrins have been implicated in these events since they mediate homotypic and heterotypic interactions of prostate cancer cells within their microenvironment. Integrins are composed of non-covalently associated $\alpha$ and $\beta$ subunits that play a role in mediating both cellcell interaction and cell-matrix interaction (Fig. 3). To date, genes for $16 \alpha$ and $8 \beta$ subunits have been identified. Both types of subunits encode single-pass transmembrane proteins with short cytoplasmic tails, except for the $\beta 4$ subunit which contains more than 100 residues [Longhurst and Jennings, 1998; Mizejewski,
Fig. 3. Overview of the integrin signaling pathway at the focal adhesion. Modulation of the integrins through RhoGTPases leads to changes in cell motility (see text for details). Activation of the G-protein protease-activated receptor 1 (PAR1) by thrombin receptor-activating pepetide (TRAP) is shown as an example in more motile (fibroblastoid) cells, Cdc42 regulates filopodia formation to allow direction sensing of chemotaxis upon stimulation. Once the direction has been established, Rac activity leads to lamellipodium extension and new focal adhesions in the direction of the gradient. Increased activation of Rac and Cdc42 leads to the down-regulation of the Rho signaling pathway that regulates stress fiber formation, but activates contractile ring formation, leading to cell migration. In less motile (epitheloid) cells, cross-talks among the RhoGTPases lead to stress fiber formation in the cell, thereby inducing cell spreading and formation of high affinity integrin binding. Panel A: Represents a scanning electron micrgraph of untreated control PC-3 cells cultured on Thermanox coverslips. Panel B: Represents PC-3 cells $1 \mathrm{~h}$ after treatment with $10 \mu \mathrm{M}$ TRAP to activate the thrombin receptor, which leads to membrane ruffling and filopodium extensions (Adapted from [Evers et al., 2000]). 

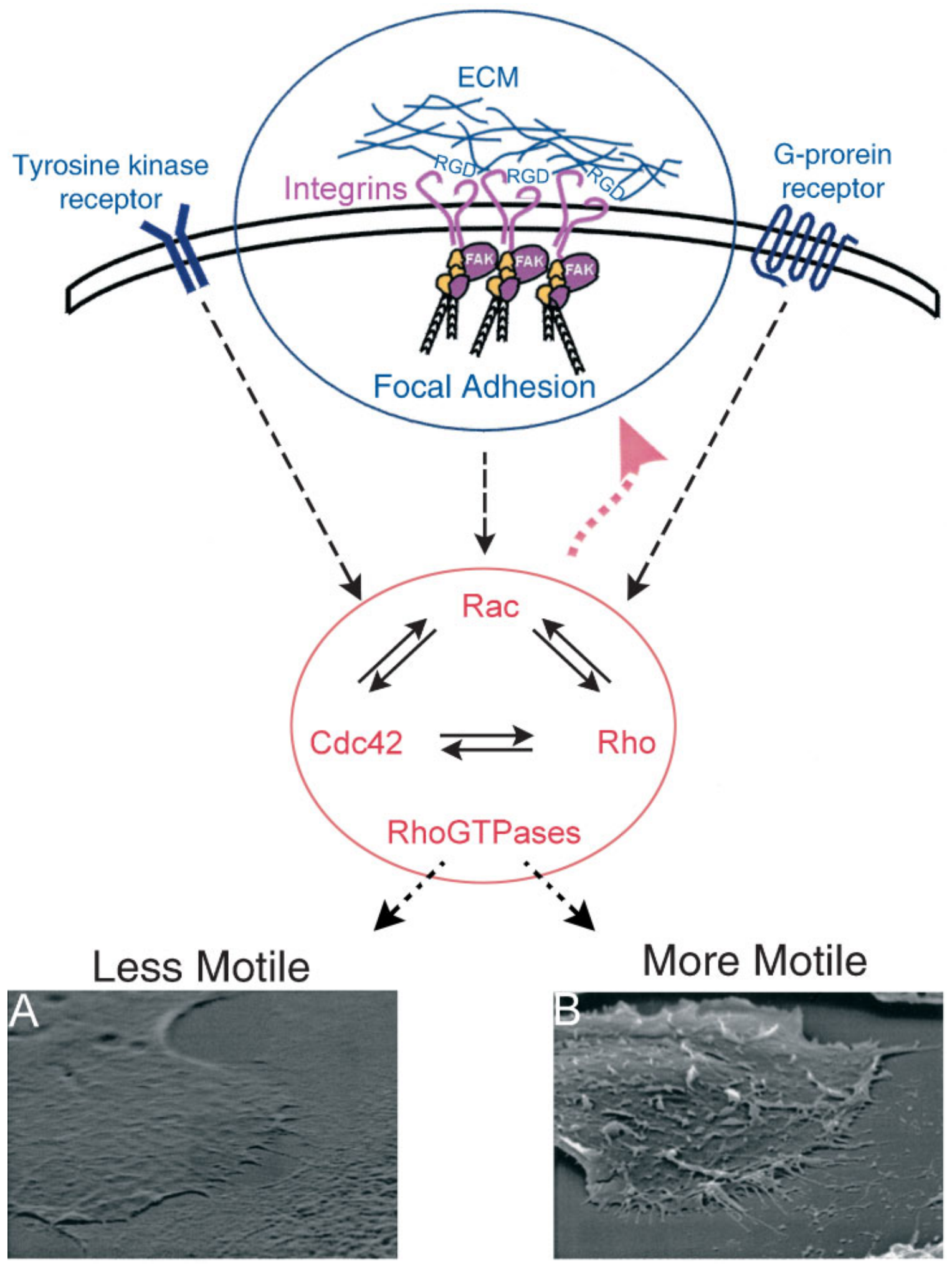

Fig. 3. 
TABLE I. Involvement of Integrins in Prostate Cancer Metastasis

\begin{tabular}{|c|c|c|c|c|}
\hline & Integrins & Ligand* & $\begin{array}{l}\text { Role in prostate } \\
\text { cancer metastasis }\end{array}$ & Reference \\
\hline Primary tumor & $\alpha 6 \beta 4$ & Laminin & Acinar morphogenesis & [Mercurio et al., 2001; \\
\hline \multirow[t]{2}{*}{ Circulatory system } & $\alpha \operatorname{IIb} \beta \operatorname{IIIa}$ & Fibrinogen, platelets & $\begin{array}{l}\text { Microembolism, arrest } \\
\text { in circulation }\end{array}$ & [Trikha et al., 1998] \\
\hline & $\alpha v \beta 3$ & $\begin{array}{l}\text { Vitronectin, } \\
\text { endothelial cells }\end{array}$ & Arrest in circulation & $\begin{array}{l}\text { [Romanov and Goligorsky, 1999; } \\
\text { Pilch et al., 2002] }\end{array}$ \\
\hline Bone & $\alpha 2 \beta 1$ & $\begin{array}{l}\text { Collagen } \\
\text { Collagen }\end{array}$ & $\begin{array}{l}\text { Growth stimulation } \\
\text { Migration invasion }\end{array}$ & [Zheng et al., 2000; Kiefer \\
\hline & $\alpha \mathrm{v} \beta 3$ & Osteopontin, osteonectin & $\begin{array}{l}\text { Growth stimulation, } \\
\text { migration, invasion }\end{array}$ & $\begin{array}{l}\text { [Festuccia et al., 1999a; } \\
\text { Angelucci et al., 2002] }\end{array}$ \\
\hline
\end{tabular}

*The major contributory role of integrin-mediated cell adhesion in prostate cancer metastasis is summarized. Although each integrin receptor can bind to multiple ligands and some ligand has multiple integrin receptors, only the contents of the ECM that are important in prostate cancer progression are listed.

1999]. The $\alpha$ subunits contain $\mathrm{Ca}^{2+}$-binding sites on the extracellular domain linked by a disulfide bond to the transmembrane portion [Argraves et al., 1987]. The $\beta$ subunits contain four repeating units of cysteine-rich motifs proximal to the transmembrane region which are joined together by disulfide bonds [Argraves et al., 1987]. At least 22 different $\alpha / \beta$ heterodimers are known, and it is the particular combination of $\alpha$ and $\beta$ subunits that determines ligand binding specificity. For example, fibronectin uniquely binds to the integrin heterodimer of $\alpha 5$ and $\beta 1$ [Argraves et al., 1987].

\section{ESCAPE FROM THE PRIMARY TUMOR SITE}

Changes in integrin expression have been documented in primary prostate tumors and prostate cancer cell lines compared to normal prostate tissue (see Table I). Immunohistochemical studies of normal, prostatic intraepithelial neoplasia (PIN), and cancerous prostate tissues indicate that loss of the laminin receptor $\alpha 6 \beta 4$ integrins occurs with increasing malignancy [Davis et al., 2001]. Low Gleason sum score correlates with increased expression of the $\alpha 3$ and $\alpha 6$ integrin subunits, while high Gleason sum score correlates with low expression of $\alpha 3$ and negative expression of $\alpha 6$ integrin subunits compared to normal prostate tissue [Schmelz et al., 2002]. Furthermore, $\beta 1 \mathrm{c}$ integrin, an alternatively spliced variant of the $\beta 1$ subunit abundantly expressed in normal prostate gland, inhibits cell proliferation [Fornaro et al., 1998] and is down-regulated in prostate carcinoma [Fornaro et al., 1996]. These changes in integrin expression are modulated upstream by many different factors including hormones and growth factors. For example, androgen- independent PC-3 prostate cancer cells transfected with androgen receptor (AR) express lower cell surface $\alpha 6 \beta 4$ integrins than the parental cells [Bonaccorsi et al., 2000]. Furthermore, these AR-positive cells exhibit decreased invasion through Matrigel, a laminin-rich reconstituted basement membrane, and less adhesion to laminin, thereby correlating reduced expression of $\alpha 6 \beta 4$ integrins with decreased invasiveness. Similarly, over expression of parathyroid hormone-related protein in PC-3 cells increases cell surface integrin expression and leads to an increase in cell adhesion to ECM proteins [Shen and Falzon, 2003].

The influence of integrin cell surface expression and interaction with the ECM in early prostate cancer progression is also illustrated by prostate acinar morphogenesis using a series of human prostatic epithelial cell lines. Nontumorigenic RWPE-1 prostate epithelial cell line form acini when grown in three-dimensional Matrigel cell cultures, while invasive WPE1-NB26 cells fail to form acini. In addition, RWPE-1 cells form acini on laminin-1, but not collagen or fibronectin, and are unable to form these structures when exposed to blocking antibodies for laminin-1 and laminin integrin receptor $\alpha 6$ or $\beta 1$ subunits [Bello-DeOcampo et al., 2001a]. WPE1-NB26 cells show a lack of $\alpha 6$ integrin expression as well as abnormal $\beta 1$ integrin expression [Bello-DeOcampo et al., 2001b]. Thus, alterations in the expression of laminin integrin receptors correlate with the ability of prostate cancer cells to escape the laminin-rich ECM support at a primary tumor site. This is further illustrated by the ability to accelerate rates of tumor growth in immunocompromised mice injected with prostate cancer cells suspended in Matrigel, which is abrogated 
by the inclusion of laminin cell adhesion peptide YIGSR [Passaniti et al., 1992]. Secretion of proteolytic enzymes by prostate cancer cells permits the cells to digest through the basement membrane to reach the microvasculature. Laminin-5 is a crucial protein in mediating cell stability, migration, and anchoring filament formation. Invasive prostate carcinoma shows a lack of protein expression of $\beta 3$ and $\gamma 2$ chains of laminin-5 and altered expression of the $\alpha 3$ chain [Hao et al., 2001]. Cleavage of laminin-5 by membrane-type 1 matrix metalloproteinase enhances migration of DU145 prostate carcinoma cells by two-fold compared to migration on uncleaved Laminin-5 thus promoting the escape of prostate cancer cells from the primary site [Udayakumar et al., 2003].

\section{SURVIVAL IN THE CIRCULATORY SYSTEM}

After prostate cancer cells cross the surrounding stroma, they enter the microvasculature in a process called intravasation and must evade assault by the immune system and the simple shear forces of blood flow. Cells appear to travel through the blood as part of a fibrin clot surrounded by other cancer cells and platelets to survive [Walz and Fenton, 1994], with platelets binding to cancer cells via the integrins $\alpha$ IIb$\beta I I I a$. Treatment with either anti-platelet antibodies or heparin inhibits platelet-tumor cell interaction [Borsig et al., 2001] and reduces lung metastasis [Stoelcker et al., 1996]. Similarly, blocking antibodies to $\alpha$ IIb $\beta I I I a$ inhibits lung colonization of mouse tail vein-injected DU145 cells [Trikha et al., 1998].

In the vasculature, thrombin may mediate cancer cell-platelet adhesion [Cooper et al., 2003] and may activate resting platelet integrins $\alpha$ IIb $\beta I I I$ a to induce platelet aggregation [Trikha and Nakada, 2002]. As well, activation of protease-activated receptor 1 (PAR1) on cancer cells by thrombin increases cell adhesion to platelets [Walz and Fenton, 1994]. Furthermore, we have previously shown that $\mathrm{VCaP}$ and PC-3 prostate cancer cell lines, both derived from osseous metastases, have increased PAR1 expression compared to normal prostate tissue [Chay et al., 2002]. Thus the ability of cancer cells to adhere and aggregate with platelets through the expression of cell surface receptors may protect them from shear stresses of the circulation and facilitate arrest in the microvasculature.

\section{INTERACTION WITH THE ENDOTHELIUM}

Hemodynamics may bring cancer cells into the bone marrow, but it alone does not explain the high frequency of prostate cancer metastasis to the bone [Yoneda, 1998]. Perhaps the presence of chemotactic gradients in the bone sinusoids contributes to the attraction, but the role cell-cell interaction plays cannot be ignored. We have shown that prostate cancer cells preferentially bind to bone marrow endothelial cells three- to five-fold more than to aortic, umbilical vein, or dermal vascular endothelial cells [Lehr and Pienta, 1998; Cooper et al., 2000b]. Furthermore, prostate cancer cells adhere preferentially directly to these bone endothelial cells and not to ECM proteins present in the bone in vitro, although the growth of bone marrow endothelial cells on bone ECM components significantly increases their affinity for PC-3 cells [Cooper et al., 2000b].

Adhesion and extravasation of prostate cancer cells from fenestrated bone marrow endothelium most likely occurs as a complex set of interactions between bone marrow endothelial cells, bone ECM components, and bone marrow stromal cells. The "dock and lock" mechanism was proposed as one explanation for extravasation and is similar to the inflammatory response of leukocytes [Honn and Tang, 1992] as both processes involve the arrest of circulating cells on the endothelium by low-affinity binding, induction of a firmer cell adhesion, extravasation, and invasion of the surrounding matrix [Buck, 1995]. During the "docking" step of inflammatory response, induced expression of $\mathrm{P}$-selectin, a type of cell adhesion molecule on platelets, leukocytes, and endothelial cells, on activated endothelial cells is responsible for the low affinity binding of leukocytes to endothelial cells [Meyer and Hart, 1998]. Similarly, interaction of $\mathrm{P}$-selectin with its ligand sialyl Lewis ${ }^{\mathrm{x}}$ carbohydrates is believed to cause the arrest of cancer cells in complex with platelets and leukocytes [Chopra et al., 1990; Bhatti et al., 1996; Borsig et al., 2001]. Indeed, elevated expression of sialyl Lewis ${ }^{\mathrm{x}}$ is detected at the surface of cancer cells and correlates with poor prognosis in prostate cancer [Martensson et al., 1995], and antibodies against sialyl Lewis ${ }^{x}$ block adhesion of neutrophils and tumor cells to endothelial cells and platelets [Geng et al., 1990]. Furthermore, fewer lung metastasis and slower tumor growth occur when colon cancer 
cells are implanted into P-selectin-deficient mice [Kim et al., 1998]. In breast and prostate cancer cells, adhesion to the microvascular endothelium of metastasis-prone tissues is also mediated in part by interactions between cancer-associated Thomsen-Friedenreich (TF) glycoantigen (Gal $\beta 1$-3GalNAc) presenting on neoplastic cells and $\beta$-galactoside binding lectin galectin-3 expressing on endothelium [Lehr and Pienta, 1998; Ellerhorst et al., 1999; Glinsky et al., 2000, 2001; Nangia-Makker et al., 2002; Khaldoyanidi et al., 2003]. This adhesion is abrogated by blocking antibodies to $\beta$-galactoside-binding lectin, galectin-3, or TF antigen [Lehr and Pienta, 1998; Glinsky et al., 2003].

Similar to inflammatory response of leukocytes, the "locking" of prostate cancer cells to endothelial cells is facilitated through the complex collaboration of integrins. We have previously reported that $\beta 1$ integrin was not involved in PC-3 prostate cancer cell-endothelial cell adhesion [Cooper et al., 2000a]. However, a more recent study showed that blocking antibodies to this subunit inhibited adhesion of PC-3 cells to bone marrow endothelial cells by $64 \%$ [Scott et al., 2001]. These conflicting results suggest the involvement of other integrins or cell adhesion molecules in prostate cancer cell adhesion to the endothelium. Indeed, cooperativity between $\alpha v \beta 3, \alpha 5 \beta 1$ and $\alpha 3 \beta 1$ integrins is necessary for PC-3 and DU145 cell adhesion to interleukin-1-stimulated human umbilical vein endothelial cells [Romanov and Goligorsky, 1999].

\section{BONE MICROENVIRONMENT}

Once cancer cells have reached the bone, they must utilize the bone microenvironment to survive and propagate. In a review of bone scans from 27 patients with limited skeletal involvement, the distribution pattern of early prostate cancer metastases was similar to the distribution of normal adult bone marrow [Imbriaco et al., 1998]. This observation supports Ewing's theory that cancer cell delivery to the bone is simply a reflection of the volume of blood flow [Ewing, 1928]. However, theories of preferential adhesion and the potential role of chemoattractants in colonization and subsequent growth are not discounted [Keller et al., 2001; Taichman et al., 2002; Cooper et al., 2003] as there is little doubt that the bone microenvironment provides a rich "soil" for the prostate cancer cell "seeds" [Paget, 1889]. For example, bone extracts induce at least a three-fold increase in invasion by PC-3 and DU145 cells compared with brain and other tissue extracts, demonstrating that bone contains significant migration and chemoinvasion promoting factors for prostate cancer cells [Jacob et al., 1999]. By purifying the bone extract, osteonectin was identified as the chemoattractant that promoted prostate cancer cell invasion [Jacob et al., 1999]. Blocking antibodies to the $\alpha v \beta 3$ integrins have been shown to reduce prostate cancer cell adhesion to crude bone protein extract by $94 \%$ [Hullinger et al., 1998], suggesting the importance of the integrins in the process.

Numerous other factors contribute to prostate cancer cell proliferation in the bone, and many are mediated through the engagement of integrin receptors. Unlike prostate epithelial associated ECM, the main component of bone ECM is collagen type I which is a ligand for $\alpha 2 \beta 1$ and $\alpha 3 \beta 1$ integrins. Greater proliferation rates for prostate cancer cells are observed in cells grown on collagen I compared to plastic or fibronectin substrates; cell signaling through phosphatidylinositol 3-kinase (PI3K) and increased expression of cyclin D1 are implicated in this process [Kiefer and Farach-Carson, 2001]. Interestingly, osteopontin, a non-collagenous bone ECM component, stimulates proliferation of quiescent prostate epithelial cells more than collagen in an integrin-mediated manner [Elgavish et al., 1998], stimulates anchorage-independent growth of the human prostate cancer cell lines LNCaP and C4-2 [Thalmann et al., 1999], and induces PC-3 cell migration and invasion via $\alpha \mathrm{v} \beta 3$ integrin function [Angelucci et al., 2002].

Although more than $95 \%$ of the bone ECM is composed of collagen type I, other proteins are also deposited by osteoblasts during bone formation [Hauschka et al., 1986]. Co-culture of PC-3 cells with osteoblasts reveals that transforming growth factor- $\beta 1$ (TGF- $\beta$ ) produced by osteoblasts stimulates PC-3 cell migration and invasion as well as increases $\alpha 2 \beta 1$ and $\alpha 3 \beta 1$ integrins expressions [Festuccia et al., 1999a]. Furthermore, osteoblast-conditioned medium stimulates the release of proteolytic enzymes urokinase plasminogen activator and matrix metalloproteinase-9 from prostate cancer cells [Festuccia et al., 1999b].

Although factors in the bone microenvironment promote prostate cancer cell growth, 
prostate cancer cells also contribute to bone remodeling in a "vicious cycle" [Chung, 2003]. Because prostate cancer metastases are usually osteoblastic in nature, the role of bone morphogenetic proteins (BMPs) in the course of bone metastasis is quite intriguing since they contribute to bone formation. Bentley et al. [1992] first reported that the expression of BMP-6, a member of the TGF- $\beta$ superfamily, was detected in prostate tissue samples of over $50 \%$ of patients with clinically defined metastatic prostate cancer, but not non-metastatic or benign prostate samples. Subsequent studies have confirmed the increased expression of BMP-6 in metastatic prostate cancer cells [Barnes et al., 1995; Hamdy et al., 1997; Autzen et al., 1998; Thomas and Hamdy, 2000]. It is believed that secretion of BMP-6, among other proteins, by prostate cancer cells contributes to osteoblastic lesions because BMP-6 stimulates osteoblastic differentiation of pluripotent mesenchymal [Ebisawa et al., 1999]. Furthermore, osteoblastic differentiation requires the activation of focal adhesion kinase (FAK), an immediate effector of the integrin signaling pathway [Tamura et al., 2001].

\section{INTEGRIN REGULATION OF MOTILITY AND DYNAMIC CELL-SUBSTRATE INTERACTIONS}

As discussed above, many steps of the metastatic cascade involve the establishment and termination of adhesive interactions between cancer cells and the ECM via integrins. However, integrins also regulate intracellular signaling pathways that control cytoskeletal organization, force generation, and survival [Hood and Cheresh, 2002]. This signal transduction is modulated in two directions: activation of integrins to bind to ligands produces "inside-out" signaling and generation of ligand bound integrins activates downstream intracellular kinases and GTPases causing "outside-in" signaling. In this "outside-in" signaling, ligand bound integrins cluster with structural and catalytic focal adhesion-associated proteins at cell-ECM junctions called focal adhesions. Because integrins do not possess kinase activity, the focal adhesion-associated protein FAK initiates the intracellular signaling cascade using its ability to recruit downstream effectors to the focal adhesion [Hood and Cheresh, 2002]. In prostate cancer, the highly tumorigenic PC-3 and DU145 cell lines have increased expression of FAK compared to the poorly tumorigenic LNCaP cells, suggesting a differential modulation of the integrin signaling pathway in metastatic prostate cancer cells [Slack et al., 2001].

Cell motility are a coordination of focal adhesion assembly at the leading edge of motile cells, providing traction for cell migration, and focal adhesion disassembly at the trailing edge of these cells, resulting in forward movement [Sastry and Burridge, 2000]. RhoGTPases, activated through integrin-mediated, focal adhesion-localized FAK and other tyrosine kinases, and G-protein receptors, appear to be key facilitators of these dynamics. These proteins and their associated downstream signals are elevated in malignant tissues but are almost non-existent in normal tissues and benign hyperplasias [Fritz et al., 2002; Kamai et al., 2002; Kostenuik et al., 1996].

Currently there are at least 18 known members of RhoGTPases. The best-characterized are Cdc42, Rac, and Rho [Sahai and Marshall, 2002]. Activated Cdc42 produces filopodia, actin-rich spikes that establish cell polarity by sensing tactic signals [Arthur and Burridge, 2001]. These extended antennae allow cells to detect changes in their surrounding and transduce intracellular signals to adjust to their microenvironment, a property which is crucial in cancer metastasis. Activated Rac coordinates focal adhesion assembly in lamellipodium and membrane ruffling [Ridley et al., 1992; Nobes and Hall, 1995; Clark et al., 1998]. These new focal adhesions establish a path for cancer cells to begin their quest to find more enriched "soil." Activated Rho generates contractile forces that push a cell body toward the leading edge and can stimulate other downstream signaling pathways leading to stress fiber formation, cell contraction, or actin polymerization depending on cross-talk between Rac, Cdc42, and other Rho regulatory proteins [Ridley, 2001]. For example, inhibition of Rho kinase, a Rho downstream target, decreases prostate cancer cell chemotactic migration in vitro and tumor growth and angiogenesis in vivo [Somlyo et al., 2000, 2003]. As well, a putative Rho regulatory protein was recently identified that encodes a novel Src homology 3 domain-containing guanine nucleotide exchange factor (CSGEF) [Qi et al., 2003]. Expressed only in prostate and liver tissues, CSGEF mRNA levels are increased two-fold in the LNCaP prostate cancer 
cell line after androgen treatment, suggesting a possible role of CSGEF in modulating prostate cancer cell metastasis. G-protein receptor PAR1 activation of Rho similarly induces actin cytoskeletal reorganization (reviewed in [Whitehead et al., 2001]). In prostate cancer cells, this activation contributes to increased prostate cancer invasiveness [Chay et al., 2002; Cooper et al., 2003; Greenberg et al., 2003] and increased production of stress fibers in $\mathrm{LNCaP}$ cells treated with thrombin [Greenberg et al., 2003].

\section{PROSPECT: CAN INTEGRINS BE USED AS TARGETS TO PREVENT OR TREAT BONE METASTASES?}

Prostate cancer cells with varying degrees of malignancy exhibit differential expression of integrin receptors which leads to the ability of these cells to develop preferential binding or "sensing" of the microenvironment through different integrins [Edlund et al., 2001]. This raises questions to the importance of integrins in prostate cancer bone metastasis and to their feasibility as therapeutic targets. Unfortunately, the exact integrins involved in the various steps of prostate cancer metastasis remain undefined (See Table I). Furthermore, the signaling pathways responsible for the regulation of the cell surface expression of integrins are unclear. For example, will inhibiting the "sensing" mechanism of the cancer cells through inhibition of the Cdc42 signaling pathway be sufficient to suppress metastasis? Or is there other mechanism(s) at work? The affinity and avidity of the integrin receptors can be modulated by many factors both from the outside and the inside of cells. Weakly attached cells cannot generate enough force for movement whereas highly adhesive forces can render cell immobility. We know that the ECM protein substrates regulate the affinity of the integrins, but what factors are regulating the avidity of the integrins? Zheng et al. [2000] have shown that $\mathrm{LNCaP}$ cells use the $\alpha \mathrm{v} \beta 3$ integrins to adhere to vitronectin and osteopontin. However, av $\beta 3$ mediated cell migration and PI3K activation, through its downstream serine/threonine kinase Akt, upon interaction with vitronectin, whereas adhesion to osteopontin did not induce avß3-mediated cell migration and PI3K/AKT pathway activation, thus suggesting some unknown mechanism co-modulating the "outside- in" signaling pathway. Growth factors and signaling through the G-protein-coupled receptors have been known to activate RhoGTPases (reviewed in [Kjoller and Hall, 1999]). Which factor(s) in the microenvironments of the primary tumor, the circulation, and the target organ can activate integrin-mediated adhesion, dynamic cell structure, migration, and invasion? The answers to these questions will lead not only to a better understanding of the biology of prostate cancer metastasis but should also lead to the identification of therapeutic targets for the prevention ant treatment of prostate cancer metastasis.

\section{ACKNOWLEDGMENTS}

The authors thank Chris Neeley and the Electron Microscopy Core Facility for their assistance with scanning electron microscopy.

\section{REFERENCES}

Angelucci A, Festuccia C, D’Andrea G, Teti A, Bologna M. 2002. Osteopontin modulates prostate carcinoma invasive capacity through RGD-dependent upregulation of plasminogen activators. Biol Chem 383:229-234.

Argraves WS, Suzuki S, Arai H, Thompson K, Pierschbacher MD, Ruoslahti E. 1987. Amino acid sequence of the human fibronectin receptor. J Cell Biol 105: 1183-1190.

Arthur WT, Burridge K. 2001. RhoA inactivation by p190RhoGAP regulates cell spreading and migration by promoting membrane protrusion and polarity. Mol Biol Cell 12:2711-2720.

Autzen P, Robson CN, Bjartell A, Malcolm AJ, Johnson MI, Neal DE, Hamdy FC. 1998. Bone morphogenetic protein6 in skeletal metastases from prostate cancer and other common human malignancies. Br J Cancer 78:12191223.

Barnes J, Anthony CT, Wall N, Steiner MS. 1995. Bone morphogenetic protein- 6 expression in normal and malignant prostate. World J Urol 13:337-343.

Bello-DeOcampo D, Kleinman HK, Deocampo ND, Webber MM. 2001a. Laminin-1 and $\alpha 6 \beta 1$ integrin regulate acinar morphogenesis of normal and malignant human prostate epithelial cells. Prostate 46:142-153.

Bello-DeOcampo D, Kleinman HK, Webber MM. 2001b. The role of $\alpha 6 \beta 1$ integrin and EGF in normal and malignant acinar morphogenesis of human prostatic epithelial cells. Mutat Res 480-481:209-217.

Bentley H, Hamdy FC, Hart KA, Seid JM, Williams JL, Johnstone D, Russell RG. 1992. Expression of bone morphogenetic proteins in human prostatic adenocarcinoma and benign prostatic hyperplasia. Br J Cancer 66: 1159-1163.

Bhatti RA, Gadarowski J, Ray P. 1996. Potential role of platelets and coagulation factors in the metastasis of prostatic cancer. Invasion Metastasis 16:49-55.

Bonaccorsi L, Carloni V, Muratori M, Salvadori A, Giannini A, Carini M, Serio M, Forti G, Baldi E. 2000. Androgen 
receptor expression in prostate carcinoma cells suppresses $\alpha 6 \beta 4$ integrin-mediated invasive phenotype. Endocrinology 141:3172-3182.

Borsig L, Wong R, Feramisco J, Nadeau DR, Varki NM, Varki A. 2001. Heparin and cancer revisited: Mechanistic connections involving platelets, P-selectin, carcinoma mucins, and tumor metastasis. Proc Natl Acad Sci USA 98:3352-3357.

Bubendorf L, Schopfer A, Wagner U, Sauter G, Moch H, Willi N, Gasser TC, Mihatsch MJ. 2000. Metastatic patterns of prostate cancer: an autopsy study of 1,589 patients. Hum Pathol 31:578-583.

Buck CA. 1995. Adhesion mechanisms controlling cell-cell and cell-matrix interactions during the metastatic process. In Mendelsohn J, Howley PM, Israel MA, Liotta LA ( eds): "The Molecular Basis of Cancer." Philadelphia: W.B. Saunders Company, pp 172-205.

Chay CH, Cooper CR, Gendernalik JD, Dhanasekaran SM, Chinnaiyan AM, Rubin MA, Schmaier AH, Pienta KJ. 2002. A functional thrombin receptor (PAR1) is expressed on bone-derived prostate cancer cell lines. Urology 60: $760-765$.

Cheville JC, Tindall D, Boelter C, Jenkins R, Lohse CM, Pankratz VS, Sebo TJ, Davis B, Blute ML. 2002. Metastatic prostate carcinoma to bone: clinical and pathologic features associated with cancer-specific survival. Cancer 95:1028-1036.

Chopra H, Fligiel SE, Hatfield JS, Nelson KK, Diglio CA, Taylor JD, Honn KV. 1990. An in vivo study of the role of the tumor cell cytoskeleton in tumor cell-plateletendothelial cell interactions. Cancer Res 50:7686-7696.

Chung LW. 2003. Prostate carcinoma bone-stroma interaction and its biologic and therapeutic implications. Cancer 97:772-778.

Clark EA, King WG, Brugge JS, Symons M, Hynes RO. 1998. Integrin-mediated signals regulated by members of the rho family of GTPases. J Cell Biol 142:573-586.

Cooper CR, McLean L, Mucci NR, Poncza P, Pienta KJ. 2000a. Prostate cancer cell adhesion to quiescent endothelial cells is not mediated by $\beta 1$ integrin subunit. Anticancer Res 20:4159-4162.

Cooper CR, McLean L, Walsh M, Taylor J, Hayasaka S, Bhatia J, Pienta KJ. 2000b. Preferential adhesion of prostate cancer cells to bone is mediated by binding to bone marrow endothelial cells as compared to extracellular matrix components in vitro. Clin Cancer Res 6 : 4839-4847.

Cooper CR, Chay CH, Gendernalik JD, Lee HL, Bhatia J, Taichman RS, McCauley LK, Keller ET, Pienta KJ. 2003. Stromal factors involved in prostate carcinoma metastasis to bone. Cancer 97:739-747.

Davis TL, Cress AE, Dalkin BL, Nagle RB. 2001. Unique expression pattern of the $\alpha 6 \beta 4$ integrin and laminin -5 in human prostate carcinoma. Prostate 46:240-248.

Ebisawa T, Tada K, Kitajima I, Tojo K, Sampath TK, Kawabata M, Miyazono K, Imamura T. 1999. Characterization of bone morphogenetic protein- 6 signaling pathways in osteoblast differentiation. J Cell Sci 112(Pt. 20): $3519-3527$.

Edlund M, Miyamoto T, Sikes RA, Ogle R, Laurie GW, Farach-Carson MC, Otey CA, Zhau HE, Chung LW. 2001. Integrin expression and usage by prostate cancer cell lines on laminin substrata. Cell Growth Differ 12:99-107.
Elgavish A, Prince C, Chang PL, Lloyd K, Lindsey R, Reed R. 1998. Osteopontin stimulates a subpopulation of quiescent human prostate epithelial cells with high proliferative potential to divide in vitro. Prostate 35 : 83-94.

Ellerhorst J, Nguyen T, Cooper DN, Lotan D, Lotan R. 1999. Differential expression of endogenous galectin-1 and galectin-3 in human prostate cancer cell lines and effects of overexpressing galectin-1 on cell phenotype. Int J Oncol 14:217-224.

Ellis WJ, Pfitzenmaier J, Colli J, Arfman E, Lange PH, Vessella RL. 2003. Detection and isolation of prostate cancer cells from peripheral blood and bone marrow. Urology 61:277-281.

Evers EE, Zondag GC, Malliri A, Price LS, ten Klouster JP, van der Kammen RA, Collard JG. 2000. Rho family proteins in cell adhesion and cell migration. Eur J Cancer 36:1269-1274.

Ewing J. 1928. "A treatise on tumors." Philadelphia: WB Saunders Company.

Festuccia C, Bologna M, Gravina GL, Guerra F, Angelucci A, Villanova I, Millimaggi D, Teti A. 1999a. Osteoblast conditioned media contain TGF $\beta 1$ and modulate the migration of prostate tumor cells and their interactions with extracellular matrix components. Int $\mathrm{J}$ Cancer 81: 395-403.

Festuccia C, Giunciuglio D, Guerra F, Villanova I, Angelucci A, Manduca P, Teti A, Albini A, Bologna M. 1999b. Osteoblasts modulate secretion of urokinase-type plasminogen activator (uPA) and matrix metalloproteinase-9 (MMP-9) in human prostate cancer cells promoting migration and matrigel invasion. Oncol Res 11: 17-31.

Fidler IJ. 2002. The organ microenvironment and cancer metastasis. Differentiation 70:498-505.

Fornaro M, Tallini G, Bofetiado CJ, Bosari S, Languino LR. 1996. Down-regulation of beta $1 C$ integrin, an inhibitor of cell proliferation, in prostate carcinoma. Am J Pathol 149:765-773.

Fornaro M, Manzotti M, Tallini G, Slear AE, Bosari S, Ruoslahti E, Languino LR. 1998. Beta1C integrin in epithelial cells correlates with a nonproliferative phenotype: forced expression of beta1C inhibits prostate epithelial cell proliferation. Am J Pathol 153:1079-1087.

Fritz G, Brachetti C, Bahlmann F, Schmidt M, Kaina B. 2002. Rho GTPases in human breast tumours: expression and mutation analyses and correlation with clinical parameters. Br J Cancer 87:635-644.

Geng JG, Bevilacqua MS, Moore KL, McIntyre TM, Prescott SM, Kim JM, Bliss GA, Zimmerman GA, McEver RP. 1990. Rapid neutrophil adhesion to activated endothelium mediated by GMP-140. Nature 343:757760 .

Glinsky VV, Huflejt ME, Glinsky GV, Deutscher SL, Quinn TP. 2000. Effects of Thomsen-Friedenreich antigenspecific peptide $\mathrm{P}-30$ on $\beta$-galactoside-mediated homotypic aggregation and adhesion to the endothelium of MDA-MB-435 human breast carcinoma cells. Cancer Res 60:2584-2588.

Glinsky VV, Glinsky GV, Rittenhouse-Olson K, Huflejt ME, Glinskii OV, Deutscher SL, Quinn TP. 2001. The role of Thomsen-Friedenreich antigen in adhesion of human breast and prostate cancer cells to the endothelium. Cancer Res 61:4851-4857. 
Glinsky VV, Glinsky GV, Glinskii OV, Huxley VH, Turk JR, Mossine VV, Deutscher SL, Pienta KJ, Quinn TP. 2003. Intravascular metastatic cancer cell homotypic aggregation at the sites of primary attachment to the endothelium. Cancer Res 63:3805-3811.

Greenberg DL, Mize GJ, Takayama TK. 2003. Proteaseactivated receptor mediated RhoA signaling and cytoskeletal reorganization in LNCaP cells. Biochemistry 42: 702-709.

Hamdy FC, Autzen P, Robinson MC, Horne CH, Neal DE, Robson CN. 1997. Immunolocalization and messenger RNA expression of bone morphogenetic protein- 6 in human benign and malignant prostatic tissue. Cancer Res 57:4427-4431.

Hao J, Jackson L, Calaluce R, McDaniel K, Dalkin BL, Nagle RB. 2001. Investigation into the mechanism of the loss of laminin 5 ( $\alpha 3 \beta 3 \gamma 2)$ expression in prostate cancer. Am J Pathol 158:1129-1135.

Hauschka PV, Mavrakos AE, Iafrati MD, Doleman SE, Klagsbrun M. 1986. Growth factors in bone matrix. Isolation of multiple types by affinity chromatography on heparin-Sepharose. J Biol Chem 261:1266512674.

Honn KV, Tang DG. 1992. Adhesion molecules and tumor cell interaction with endothelium and subendothelial matrix. Cancer Metastasis Rev 11:353-375.

Hood JD, Cheresh DA. 2002. Role of integrins in cell invasion and migration. Nat Rev Cancer 2:91-100.

Hullinger TG, McCauley LK, DeJoode ML, Somerman MJ. 1998. Effect of bone proteins on human prostate cancer cell linesin vitro. Prostate 36:14-22.

Imbriaco M, Larson SM, Yeung HW, Mawlawi OR, Erdi Y, Venkatraman ES, Scher HI. 1998. A new parameter for measuring metastatic bone involvement by prostate cancer: The Bone Scan Index. Clin Cancer Res 4:17651772.

Jacob K, Webber M, Benayahu D, Kleinman HK. 1999. Osteonectin promotes prostate cancer cell migration and invasion: a possible mechanism for metastasis to bone. Cancer Res 59:4453-4457.

Jemal A, Murray T, Samuels A, Ghafoor A, Ward E, Thun MJ. 2003. Cancer statistics, 2003. CA Cancer J Clin 53:5-26.

Kamai T, Arai K, Sumi S, Tsujii T, Honda M, Yamanishi T, Yoshida KI. 2002. The Rho/Rho-kinase pathway is involved in the progression of testicular germ cell tumour. BJU Int 89:449-453.

Keller ET, Zhang J, Cooper CR, Smith PC, McCauley LK, Pienta KJ, Taichman RS. 2001. Prostate carcinoma skeletal metastases: cross-talk between tumor and bone. Cancer Metastasis Rev 20:333-349.

Khaldoyanidi SK, Glinsky VV, Sikora L, Glinskii AB, Mossine VV, Quinn TP, Glinsky GV, Sriramarao P. 2003. MDA-MB-435 human breast carcinoma cell homo- and heterotypic adhesion under flow conditions is mediated in part by Thomsen-Friedenreich antigen-galectin-3 interactions. J Biol Chem 278:4127-4134.

Kiefer JA, Farach-Carson MC. 2001. Type I collagenmediated proliferation of PC-3 prostate carcinoma cell line: implications for enhanced growth in the bone microenvironment. Matrix Biol 20:429-437.

Kim YJ, Borsig L, Varki NM, Varki A. 1998. P-selectin deficiency attenuates tumor growth and metastasis. Proc Natl Acad Sci U S A 95:9325-9330.
Kjoller L, Hall A. 1999. Signaling to Rho GTPases. Exp Cell Res 253:166-179.

Kostenuik PJ, Sanchez-Sweatman O, Orr FW, Singh G. 1996. Bone cell matrix promotes the adhesion of human prostatic carcinoma cells via the $\alpha 2 \beta 1$ integrin. Clin Exp Metastasis 14:19-26.

Lehr JE, Pienta KJ. 1998. Preferential adhesion of prostate cancer cells to a human bone marrow endothelial cell line. J Natl Cancer Inst 90:118-123.

Longhurst C, Jennings L. 1998. Integrin-mediated signal transduction. Cell Mol Lif Sci 54:514-526.

Luzzi KJ, MacDonald IC, Schmidt EE, Kerkvliet N, Morris VL, Chambers AF, Groom AC. 1998. Multistep nature of metastatic inefficiency: dormancy of solitary cells after successful extravasation and limited survival of early micrometastases. Am J Pathol 153:865-873.

MacDonald IC, Groom AC, Chambers AF. 2002. Cancer spread and micrometastasis development: Quantitative approaches for in vivo models. Bioessays 24:885-893.

Martensson S, Bigler SA, Brown M, Lange PH, Brawer MK, Hakomori S. 1995. Sialyl-Lewis ${ }^{\mathrm{x}}$ and related carbohydrate antigens in the prostate. Hum Pathol 26:735-739.

Mercurio AM, Rabinovitz I, Shaw LM. 2001. The $\alpha 6 \beta 4$ integrin and epithelial cell migration. Curr Opin Cell Biol 13:541-545.

Meyer T, Hart I. 1998. Mechanisms of tumor metastasis. Eu J Cancer 34:214-221.

Mizejewski GJ. 1999. Role of integrins in cancer: survey of expression patterns. Proc Soc Exp Biol Med 222:124138.

Nangia-Makker P, Hogan V, Honjo Y, Baccarini S, Tait L, Bresalier R, Raz A. 2002. Inhibition of human cancer cell growth and metastasis in nude mice by oral intake of modified citrus pectin. J Natl Cancer Inst 94:1854-1862.

Naumov GN, MacDonald IC, Chambers AF, Groom AC. 2001. Solitary cancer cells as a possible source of tumour dormancy? Semin Cancer Biol 11:271-276.

Naumov GN, MacDonald IC, Weinmeister PM, Kerkvliet N, Nadkarni KV, Wilson SM, Morris VL, Groom AC, Chambers AF. 2002. Persistence of solitary mammary carcinoma cells in a secondary site: a possible contributor to dormancy. Cancer Res 62:2162-2168.

Nobes CD, Hall A. 1995. Rho, Rac, and Cdc42 GTPases regulate the assembly of multimolecular focal complexes associated with actin stress fibers, lamellipodia, and filopodia. Cell 81:53-62.

Paget S. 1889. The distribution of secondary gorowths in cancer of the breast. Lancet 1:571.

Passaniti A, Isaacs JT, Haney JA, Adler SW, Cujdik TJ, Long PV, Kleinman HK. 1992. Stimulation of human prostatic carcinoma tumor growth in athymic mice and control of migration in culture by extracellular matrix. Int J Cancer 51:318-324.

Pilch J, Habermann R, Felding-Habermann B. 2002. Unique ability of integrin $\alpha v \beta 3$ to support tumor cell arrest under dynamic flow conditions. J Biol Chem 277: 21930-21938.

Qi H, Fournier A, Grenier J, Fillion C, Labrie Y, Labrie C. 2003. Isolation of the novel human guanine nucleotide exchange factor Src homology 3 domain-containing guanine nucleotide exchange factor (SGEF) and of Cterminal SGEF, an N-terminally truncated form of SGEF, the expression of which is regulated by androgen in prostate cancer cells. Endocrinology 144:1742-1752. 
Ridley AJ. 2001. Rho GTPases and cell migration. J Cell Sci 114:2713-2722.

Ridley AJ, Paterson HF, Johnston CL, Diekmann D, Hall A. 1992. The small GTP-binding protein Rac regulates growth factor-induced membrane ruffling. Cell 70:401410.

Romanov VI, Goligorsky MS. 1999. RGD-recognizing integrins mediate interactions of human prostate carcinoma cells with endothelial cells in vitro. Prostate 39: 108-118.

Rosol TJ, Tannehill-Gregg SH, LeRoy BE, Mandl S, Contag CH. 2003. Animal models of bone metastasis. Cancer 97: 748-757.

Rubin MA, Putzi M, Mucci N, Smith DC, Wojno K, Korenchuk S, Pienta KJ. 2000. Rapid ("warm”) autopsy study for procurement of metastatic prostate cancer. Clin Cancer Res 6:1038-1045.

Sahai E, Marshall CJ. 2002. Rho-GTPases and cancer. Nat Rev Cancer 2:133-142.

Sastry SK, Burridge K. 2000. Focal adhesions: a nexus for intracellular signaling and cytoskeletal dynamics. Exp Cell Res 261:25-36.

Schmelz M, Cress AE, Scott KM, Burger F, Cui H, Sallam K, McDaniel KM, Dalkin BL, Nagle RB. 2002. Different phenotypes in human prostate cancer: $\alpha 6$ or $\alpha 3$ integrin in cell-extracellular adhesion sites. Neoplasia 4:243-254.

Scott LJ, Clarke NW, George NJ, Shanks JH, Testa NG, Lang SH. 2001. Interactions of human prostatic epithelial cells with bone marrow endothelium: binding and invasion. Br J Cancer 84:1417-1423.

Shen X, Falzon M. 2003. Parathyroid hormone-related protein upregulates integrin expression via an intracrine pathway in PC-3 prostate cancer cells. Regul Pept 113: $17-29$.

Slack JK, Adams RB, Rovin JD, Bissonette EA, Stoker CE, Parsons JT. 2001. Alterations in the focal adhesion kinase/Src signal transduction pathway correlate with increased migratory capacity of prostate carcinoma cells. Oncogene 20:1152-1163.

Somlyo AV, Bradshaw D, Ramos S, Murphy C, Myers CE, Somlyo AP. 2000. Rho-kinase inhibitor retards migration and in vivo dissemination of human prostate cancer cells. Biochem Biophys Res Commun 269:652-659.

Somlyo AV, Phelps C, Dipierro C, Eto M, Read P, Barrett M, Gibson JJ, Burnitz MC, Myers C, Somlyo AP. 2003. Rho kinase and matrix metalloproteinase inhibitors cooperate to inhibit angiogenesis and growth of human prostate cancer xenotransplants. Faseb J 17:223-234.

Stoelcker B, Hafner M, Orosz P, Nieswandt B, Mannel DN. 1996. Role of adhesion molecules and platelets in TNF- induced adhesion of tumor cells to endothelial cells: implications for experimental metastasis. J Inflamm 46: 155-167.

Taichman RS, Cooper C, Keller ET, Pienta KJ, Taichman NS, McCauley LK. 2002. Use of the stromal cell-derived factor-1/CXCR4 pathway in prostate cancer metastasis to bone. Cancer Res 62:1832-1837.

Tamura Y, Takeuchi Y, Suzawa M, Fukumoto S, Kato M, Miyazono K, Fujita T. 2001. Focal adhesion kinase activity is required for bone morphogenetic proteinSmad1 signaling and osteoblastic differentiation in murine MC3T3-E1 cells. J Bone Miner Res 16:17721779 .

Thalmann GN, Sikes RA, Devoll RE, Kiefer JA, Markwalder R, Klima I, Farach-Carson CM, Studer UE, Chung LW. 1999. Osteopontin: possible role in prostate cancer progression. Clin Cancer Res 5:22712277.

Thomas BG, Hamdy FC. 2000. Bone morphogenetic protein-6: potential mediator of osteoblastic metastases in prostate cancer. Prostate Cancer Prostatic Dis 3:283285.

Trikha M, Nakada MT. 2002. Platelets and cancer: implications for antiangiogenic therapy. Semin Thromb Hemost 28:39-44.

Trikha M, Raso E, Cai Y, Fazakas Z, Paku S, Porter AT, Timar J, Honn KV. 1998. Role of $\alpha \operatorname{IIb} \beta 3$ integrin in prostate cancer metastasis. Prostate 35:185-192.

Udayakumar TS, Chen ML, Bair EL, Von Bredow DC, Cress AE, Nagle RB, Bowden GT. 2003. Membrane type1-matrix metalloproteinase expressed by prostate carcinoma cells cleaves human laminin-5 $\beta 3$ chain and induces cell migration. Cancer Res 63:2292-2299.

Varghese HJ, Davidson MT, MacDonald IC, Wilson SM, Nadkarni KV, Groom AC, Chambers AF. 2002. Activated Ras regulates the proliferation/apoptosis balance and early survival of developing micrometastases. Cancer Res 62:887-891.

Walz DA, Fenton JW. 1994. The role of thrombin in tumor cell metastasis. Invasion Metastasis 14:303-308.

Whitehead IP, Zohn IE, Der CJ. 2001. Rho GTPasedependent transformation by $\mathrm{G}$ protein-coupled receptors. Oncogene 20:1547-1555.

Yoneda T. 1998. Cellular and molecular mechanisms of breast and prostate cancer metastasis to bone. Eur J Cancer 34:240-245.

Zheng DQ, Woodard AS, Tallini G, Languino LR. 2000. Substrate specificity of $\alpha \mathrm{v} \beta 3$ integrin-mediated cell migration and phosphatidylinositol 3-kinase/AKT pathway activation. J Biol Chem 275:24565-24574. 